\title{
A P2X receptor from the tardigrade species Hypsibius dujardini with fast kinetics and sensitivity to zinc and copper
} Selvan Bavan ${ }^{1}$, Volko A Straub1, Mark L Blaxter ${ }^{2}$ and Steven J Ennion*1 Address: ${ }^{1}$ Department of Cell Physiology and Pharmacology, University of Leicester, PO Box 138, Leicester, LE1 9HN, UK and ${ }^{2}$ Institute of
Evolutionary Biology, The Ashworth laboratories, University of Edinburgh, Edinburgh, UK

Email: Selvan Bavan -sb314@le.ac.uk; Volko A Straub - vs64@le.ac.uk; Mark L Blaxter - mark.blaxter@ed.ac.uk; Steven J Ennion* - se15@le.ac.uk

* Corresponding author

Published: 20 January 2009

BMC Evolutionary Biology 2009, 9:17 doi:10.1186/147|-2148-9-17
Received: 2 January 2009

Accepted: 20 January 2009

This article is available from: http://www.biomedcentral.com/I47/-2/48/9//7

(C) 2009 Bavan et al; licensee BioMed Central Ltd.

This is an Open Access article distributed under the terms of the Creative Commons Attribution License (http://creativecommons.org/licenses/by/2.0), which permits unrestricted use, distribution, and reproduction in any medium, provided the original work is properly cited.

\begin{abstract}
Background: Orthologs of the vertebrate ATP gated P2X channels have been identified in Dictyostelium and green algae, demonstrating that the emergence of ionotropic purinergic signalling was an early event in eukaryotic evolution. However, the genomes of a number of animals including Drosophila melanogaster and Caenorhabditis elegans, both members of the Ecdysozoa superphylum, lack P2X-like proteins, whilst other species such as the flatworm Schistosoma mansoni have P2X proteins making it unclear as to what stages in evolution P2X receptors were lost. Here we describe the functional characterisation of a P2X receptor (HdP2X) from the tardigrade Hypsibius dujardini demonstrating that purinergic signalling is preserved in some ecdysozoa.
\end{abstract}

Results: ATP ( $\mathrm{EC}_{50} \sim 44.5 \mu \mathrm{M}$ ) evoked transient inward currents in HdP2X with millisecond rates of activation and desensitisation. HdP2X is antagonised by pyridoxal-phosphate-6-azophenyl-2',4' disulfonic acid $\left(\mathrm{IC}_{50} \mathrm{I} 5.0 \mu \mathrm{M}\right)$ and suramin $\left(\mathrm{IC}_{50} 22.6 \mu \mathrm{M}\right)$ and zinc and copper inhibit ATP-evoked currents with $\mathrm{IC}_{50}$ values of $62.8 \mu \mathrm{M}$ and $19.9 \mu \mathrm{M}$ respectively. Site-directed mutagenesis showed that unlike vertebrate $\mathrm{P} 2 \mathrm{X}$ receptors, extracellular histidines do not play a major role in coordinating metal binding in HdP2X. However, $\mathrm{H} 306$ was identified as playing a minor role in the actions of copper but not zinc. Ivermectin potentiated responses to ATP with no effect on the rates of current activation or decay.

Conclusion: The presence of a P2X receptor in a tardigrade species suggests that both nematodes and arthropods lost their P2X genes independently, as both traditional and molecular phylogenies place the divergence between Nematoda and Arthropoda before their divergence from Tardigrada. The phylogenetic analysis performed in our study also clearly demonstrates that the emergence of the family of seven P2X channels in human and other mammalian species was a relatively recent evolutionary event that occurred subsequent to the split between vertebrates and invertebrates. Furthermore, several characteristics of HdP2X including fast kinetics with low ATP sensitivity, potentiation by ivermectin in a channel with fast kinetics and distinct copper and zinc binding sites not dependent on histidines make HdP2X a useful model for comparative structure-function studies allowing a better understanding of $\mathrm{P} 2 \mathrm{X}$ receptors in higher organisms. 


\section{Background}

Vertebrate P2X receptors comprise a family of ligand gated ion channels activated by extracellular ATP [1]. They form homo or heteromeric trimers with each monomer consisting of intracellular amino and carboxy termini, two transmembrane domains and a large glycosylated extracellular region containing five disulphide bonds [2] and the agonist binding site [3]. Mammalian species possess seven distinct $\mathrm{P} 2 \mathrm{X}$ subtypes $\left(\mathrm{P} 2 \mathrm{X}_{1-7}\right)$ that play important roles in a wide range of physiological processes including neurotransmission, platelet aggregation, smooth muscle contractility and bone formation $[4,5]$. Many studies have also described potential roles for ATP as an extracellular signalling molecule in a range of invertebrate phyla [6] and plants $[7,8]$ leading to the assumption that ATP is a primitive signalling molecule and that the emergence of purinergic receptors occurred relatively early in evolution [9]. This assumption is supported by the definitive molecular and functional identification of $\mathrm{P} 2 \mathrm{X}$ receptors in the slime mould Dictyostelium discoideum [10], the green alga Ostreococcus tauri [11] and the choanoflagellate Monosiga brevicollis [11]. However, several non-vertebrate organisms for which full genome data are available lack P2Xlike genes, including Anopheles gambiae, Caenorhabditis elegans, Drosophila melanogaster, and Apis mellifera. Arthropods and nematodes are members of the protostome superphylum Ecdysozoa. Given that P2X receptors are present in choanoflagellates, believed to be the sister group to the Metazoa, and in some representatives of the protostome superphylum Lophotrochozoa including Schistosoma mansoni [12] and Lymnaea stagnalis [13], the absence of P2X receptors from the above fully sequenced nematode and arthropod genomes suggests a loss of this class of gene in an ancestor of the Ecdysozoa.

We identified a partial P2X-like sequence in expressed sequence tag (EST) data from the tardigrade Hypsibius dujardini. Tardigrades are microscopic animals around 200 to $500 \mu \mathrm{m}$ in length that inhabit both marine and fresh water habitats $[14,15]$. They possess a fascinating ability to desiccate into a reversible state of metabolic suspension called cryptobiosis allowing them to survive for many decades in harsh environments, such as lack of oxygen, extremes in temperature, and high pressure, before rehydration to an active state within minutes [16]. Tardigrades are placed in their own phylum, Tardigrada and share features with both arthropods and nematodes. Like arthropods they possess legs and a distinctly segmented body. However they also have a triradiate pharynx more reminiscent of the nematodes. Indeed, molecular phylogenetic analyses support tardigrades as part of the Ecdysozoa $[17,18]$. Functional confirmation that tardigrades possess P2X receptors would expand our emerging knowledge of P2X phylogeny and better estimate the pattern of loss of P2X in nematodes and arthropods. Furthermore, a better understanding of $\mathrm{P} 2 \mathrm{X}$ receptor function in simple invertebrate organisms may help shed new light on structure-function aspects of human P2X receptors in health and disease by virtue of conservation of functionally important amino acid residues between evolutionary remote $\mathrm{P} 2 \mathrm{X}$ receptors and the identification of novel P2X mediated signalling pathways. The aim of this present work therefore was to determine whether the Hypsibius dujardini EST sequence corresponds to a gene encoding a functional P2X receptor and to determine its pharmacological properties. This was achieved by expression of cRNA encoding the Hypsibius dujardini P2X gene in Xenopus oocytes to enable two electrode voltage clamp recordings of ATP evoked membrane currents. Using this approach we show that the Hypsibius dujardini EST sequence does indeed code a functional $\mathrm{P} 2 \mathrm{X}$ receptor with fast activation and desensitisation kinetics and similar to some vertebrate P2X channels, is potentiated by ivermectin and inhibited by zinc and copper.

\section{Results}

\section{Sequence analysis of HdP2X}

Existing EST data for clone Hd_mx23_13F10 consisted of $330 \mathrm{bp}$ from the $5^{\prime}$ end of a cDNA showing similarity to vertebrate P2X receptors. Sequencing of the full insert of this clone showed that it contained an insert of $1743 \mathrm{bp}$ with an open reading frame of $1440 \mathrm{bp}$. The nucleotide sequence of this cDNA has been submitted to the GenBank database [EU979525]. The coding sequence of $H d \mathrm{P} 2 \mathrm{X}$ is 480 amino acids in length and is predicted to contain intracellular amino and carboxy termini and two transmembrane helices (residues $47-67$ and $345-365$ ) by the TopPred algorithm [19] (Fig. 1). From the human P2X $\mathrm{X}_{1-7}$ family, $H d \mathrm{P} 2 \mathrm{X}$ was most similar to $\mathrm{P} 2 \mathrm{X}_{1}, \mathrm{P} 2 \mathrm{X}_{3}$ and $\mathrm{P} 2 \mathrm{X}_{4}$ with sequence identities of $36.1,36.5$ and $38.4 \%$ respectively. However, phylogenetic analysis of the HdP2X protein alongside vertebrate and other P2X sequences suggests that, like other invertebrate $\mathrm{P} 2 \mathrm{X}$ receptor proteins, $H d \mathrm{P} 2 \mathrm{X}$ does not appear to be a member of any of the seven vertebrate $\mathrm{P} 2 \mathrm{X}$ receptor subtypes, but instead represents an ortholog to the ancestor of the vertebrate paralog groups (Fig. 2). Sequence identity with the S. mansoni, D. discoideum (dP2XA), and O. tauri P2X channels was $34.2 \%, 15.6 \%$ and $26.0 \%$ respectively. $H d \mathrm{P} 2 \mathrm{X}$ contains a number of conserved features typical to P2X channels including ten cysteine residues in the extracellular domain [2], a consensus protein kinase $\mathrm{C}$ phosphorylation site in the amino terminal [20], and the lysine residues and NFR/FT motifs shown to be involved in agonist binding (Fig. 1) [21].

\section{ATP evoked currents in HdP2X with fast activation and desensitisation kinetics}

In HdP2X expressing Xenopus oocytes clamped at -60 mV, ATP evoked transient inward currents that rapidly desen- 


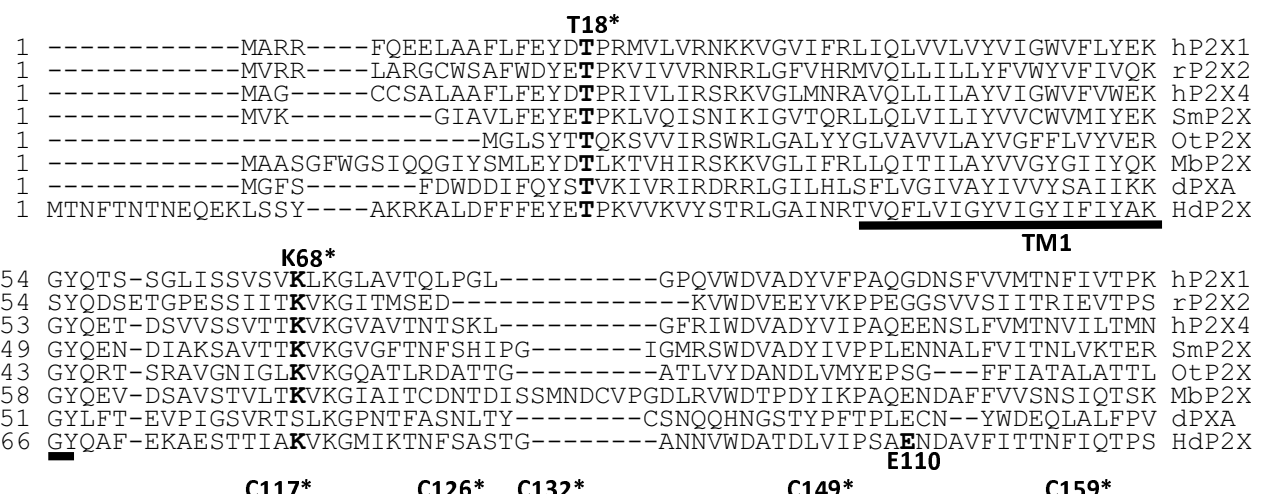

$\mathrm{C117}^{*} \mathrm{C126*} \mathrm{C132}^{*} \mathrm{C149*}$ C159* 108 QTL------GTCPESMRVHSSTCHSDDDC IAGQLDMQ GNGIRTGHCVPYYHGD-----SKTCEVSAW $r P 2 \times 2$

111 QTQ-------GLCPEIPDATT-VCKSDASCTAGSAGTHSNGVSTGRCVAFN-GS-----VKTCEVAAW hP2X4

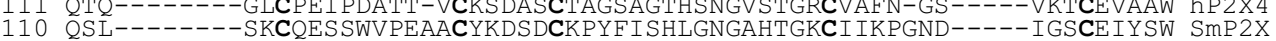

99 QAR-------GRCPGMDEDE--TCEDASACVVGTFSP--SGRMTGQCVATALKDEDGKVVKRCEVEGW OtP 2X
126 QTQRAEGWDEDPAAPVTGSASAFNCTSDADCPRFATSR--NGALTGECNTT--------ERCRIYGW MbP2X

126 QTQRAEGWDEDPAAPVTGSASAFNCTSDADCPRFATSR--NGALTGECNTTT--------ERCRIYGW MbP2X

126 QQS------GKCPEDTNNKFARCRTDSGCTAGEQVLLGNGFKTGQCVQAT-------GTCEIDGW HdP2X

$\begin{array}{lcl}\text { C165* K130 } & \text { F185* } & \text { C217* } \\ & & \end{array}$

165 CPVEVDDDIP--------RPALLREAENFTLFIKNS ISFPRFKVNRRNLVEEVNAAHMKTCLFHKT--L hP2X1

164 CPVEDGTSDN--------H-FLGKMAPNFTILIKNS IHY PKFKF SKGNIASQK-SDYLKHCTFDQD--S rP2X2

165 CPVEDDTHVP------QPAFLKAAENFTLLVKNNIWY PKFNF SKRNI LPNITTTYLKSCIYDAK--T hP2X4

166 CPLENDTLPLGR------KSFLFPMVYNYTLLIKNDINFEKFGI HRRNIQNWASKKFLRTCLYNKTDPE SMP2X

156 CPGEPEKDEV---------TVLENVGNFTVFTRISVEFP--GIPDEDGEGNMLWTNLNGTKPTLG--- OtP2X

184 GPVESKDEDDRATTDGLFYARHMPAVKNFTVYTKNTVFFORFGAKFGSTDESD-KVDVYTCTWSPTG-I MbP2X

157 TITTDHTMYA

178 CPAEVDDKPE------PPIFMEAENFTIMVKNYVTFPEFDVKRRNIPDDMKGAYINTCRYHPV--S HdP2X D183
C227*

224 HPLCPVFQLG-YVVQESGQ-NFSTLAEK-GGVVGITIDWHCDLDWHVRHCRPIYEFHGLYE---EKNLS hP2X1 221 DPYCPIFRLG-FIVEKAGE-NFTELAHK-GGVIGVI INWNCDLDLSESECNPKYSFRRLDP--KYDPAS rP2X2 224 DPFCPIFRLG-KIVENAGH-SFQDMAVE-GGIMG IQVNWDCNLDRAAS LCLPRYSFRRLDTRDVEHNVS hP2X4 229 NRFCPIFQFG-TIFEEANV-DQS IFIS--GGVIGIDIDWKCDLDWDVQYCNPTYSFRRLDD--AHAKIA SmP2X 210 ---WNLWTIN-DLLESGGM-SVKEVARK-GWDGRVDVEFDCNLDRGIDACAPKTPYT-LKQVMHPNTLS OtP2X 251 ERHCPIFKID-TILNEAGITDFENQAMRNGALITIQVNYDCNLDSSAHTCSPTYKFTRLDT---KSDLS MbP2X 212 ----OLLSFGGVSLDQASPVDSNVS IRYDGVVLFVFITYSNTYTYSTSDFKYVYSVQQIAN--TIYDVP dPXA 236 DPYCPIFTVQ-RLVELAHE-NFSVVART-GAIFGFI IEWDCNLDESVEYCLPKYQIRRIDS--VEEKIA HdP2X

\begin{tabular}{|c|c|c|}
\hline \\
\hline & 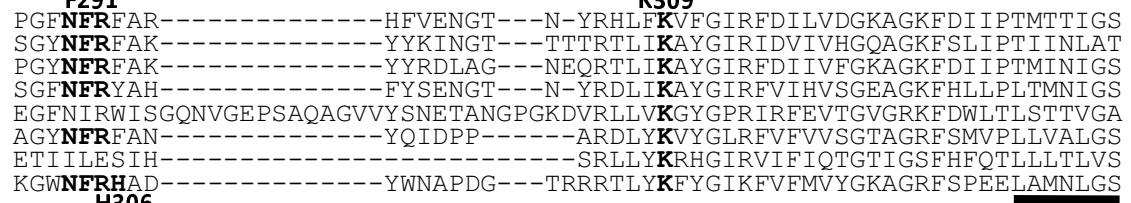 & \\
\hline & 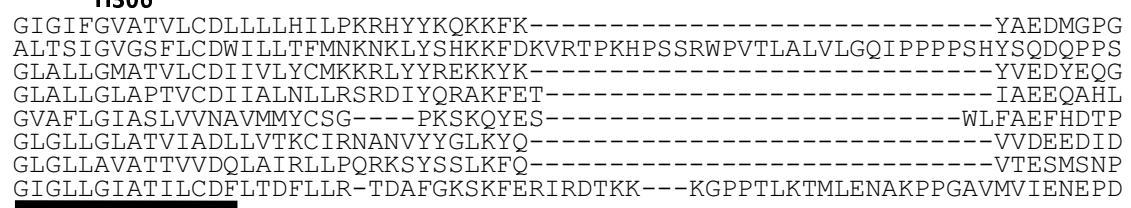 & \\
\hline & & \\
\hline & 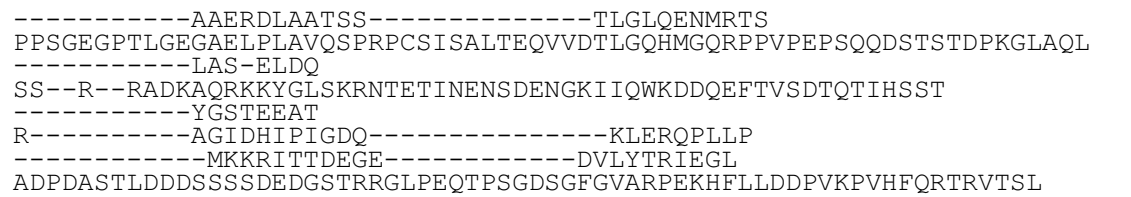 & \\
\hline
\end{tabular}

\section{Figure I}

Amino acid alignment of $H d P 2 X$. The predicted amino acid sequence of $H d P 2 X$ was aligned with human $P 2 X$, and 4 , rat $\mathrm{P} 2 \mathrm{X}_{2}$ and non vertebrate P2X channels from S. mansoni (smP2X) [I2]O. tauri (OtP2X) [II], M. brevicollis (MbP2X) [II] and D. discoideum (dP2XA) [10]. Predicted transmembrane regions in HdP2X (TopPred algorithm [19]) are depicted by black horizontal lines. Functionally important amino acid residues using human $\mathrm{P} 2 \mathrm{X}$, residue numbering (indicated by $*$ ) are highlighted in bold above the sequence including positively charged lysine residues, FT and NFR motifs, conserved cysteines and a conserved consensus protein kinase $\mathrm{C}$ phosphorylation site. Point mutations made in $\mathrm{HdP} 2 \mathrm{X}$ to investigate zinc and copper binding are indicated in bold below the sequence. 


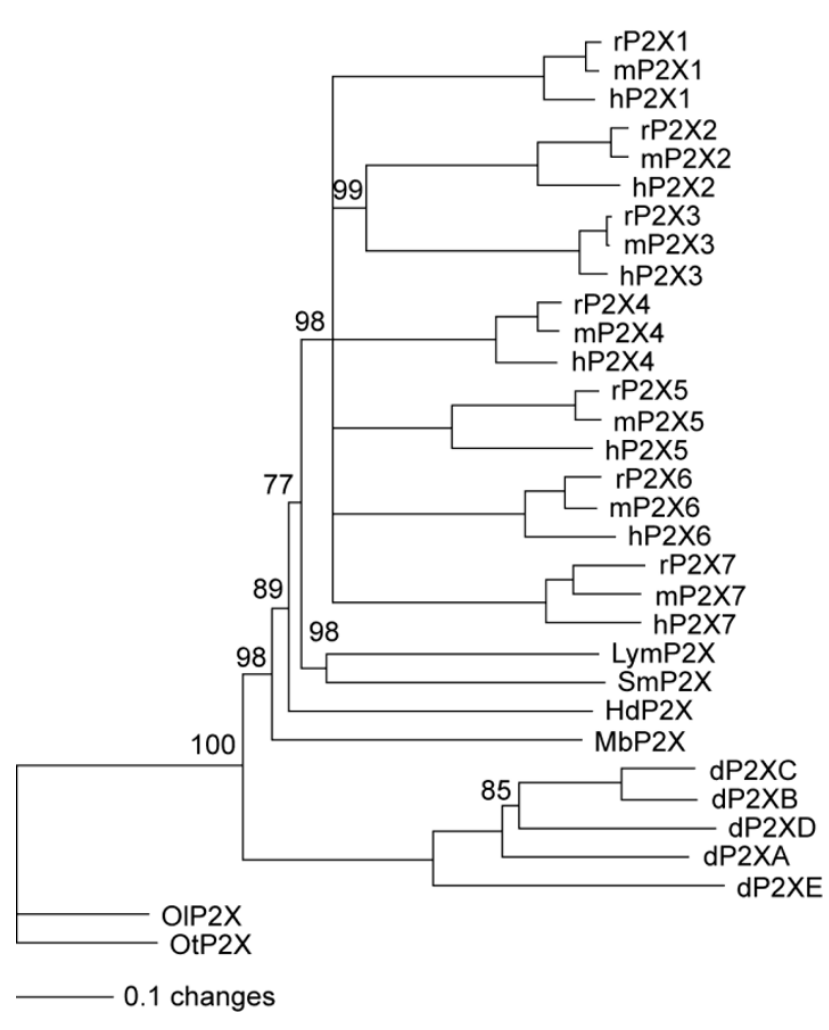

Figure 2

Phylogenetic relationships of Hypsibius dujardini P2X. Aligned protein sequences from P2X homologues from $H$. dujardini (Hd) (Tardigrada), vertebrates (represented by human $(h)$, mouse $(m)$ and rat $(r)$; these taxa have seven paralogous $\mathrm{P} 2 \mathrm{X}$ genes $\left.\left(\mathrm{P} 2 \mathrm{X}_{\mathrm{I}-7}\right)\right)$, S. mansoni (Sm) (Platyhelminthes), L. stagnalis (Lym) (Mollusca), M. brevicollis (Mb) (Choanoflagellida), D. discoideum (d) (Mycetozoa; Dictyosteliida; five paralogues) and two Ostreococcus species, 0 . tauri (Ot) and O. lucimarinus (OI) (Chlorophyta; Prasinophyceae) were analysed using Neighbour Joining and maximum parsimony methods. Both methods agreed on the well supported nodes figured in this phylogram. Nodes were supported with bootstraps of $100 \%$ unless otherwise indicated; all nodes with less than $75 \%$ bootstrap support were collapsed.

sitised during the continued presence of agonist (Fig. 3A). At $100 \mu \mathrm{M}$ ATP $\left(\sim \mathrm{EC}_{90}\right)$ the rise time from $10 \%$ to $90 \%$ peak amplitude was $71.4 \pm 2.5 \mathrm{~ms}$ and the current decay from peak to $50 \%$ peak was $289.9 \pm 16.1 \mathrm{~ms}(\mathrm{n}=39)$. The decay of the current in the continued presence of $100 \mu \mathrm{M}$ ATP was best fit with two exponentials consisting of a fast component with a time constant of $122 \pm 26 \mathrm{~ms}$ and a relative amplitude of $0.68 \pm 0.04$ and a slower component with a time constant of $627 \pm 148 \mathrm{~ms}$ and a relative amplitude of $0.32 \pm 0.04(n=6)$. As a direct comparison using the same experimental apparatus application of $100 \mu \mathrm{M}$ ATP at the fast human $\mathrm{P} 2 \mathrm{X}_{1}$ receptor gave rise and decay times of $134.5 \pm 11.0 \mathrm{~ms}$ and $727.0 \pm 88.6(\mathrm{n}=15) \mathrm{ms}$ respectively. Both $\mathrm{hP} 2 \mathrm{X}_{1}$ (Fig. 3A) and S. mansoni P2X [12] display a marked reduction in current amplitude between the very first and second applications of $100 \mu \mathrm{M}$ ATP five minutes apart $(34.39 \pm 5.46 \%$ and $45.76 \pm 5.10 \%$ reductions respectively $(\mathrm{n}=15))$ before producing stable responses with subsequent applications of agonist at five minute intervals. In contrast, with the same experimental protocol, $\mathrm{HdP} 2 \mathrm{X}$ showed a much lower reduction in current amplitude $(8.96 \pm 5.46 \%(\mathrm{n}=11))$ between first and second applications of ATP (first application mean $=-1.77$ $\pm 0.30 \mu \mathrm{A}$; second application mean $=-1.62 \pm 0.29 \mu \mathrm{A}$ (Fig. 3A) demonstrating that $H d \mathrm{P} 2 \mathrm{X}$ recovers more rapidly from desensitisation than $\mathrm{hP} 2 \mathrm{X}_{1}$ and $S$. mansoni $\mathrm{P} 2 \mathrm{X}$. The current-voltage relationship for $H d \mathrm{P} 2 \mathrm{X}$ was obtained by applying $100 \mu \mathrm{M}$ ATP at a range of holding potentials between $-60 \mathrm{mV}$ to and $+40 \mathrm{mV}$. Typical of a non selective cation channel the reversal potential was $-3.8 \mathrm{mV}(n=6)$ and the current voltage relationship showed a slight outward rectification over the range of potentials measured (Fig. 3B and 3C).

\section{Agonists}

ATP induced responses at $H d \mathrm{P} 2 \mathrm{X}$ in a concentration dependent manner with an $\mathrm{EC}_{50}$ of $44.5 \mu \mathrm{M}\left(\mathrm{pEC}_{50} 4.5 \pm\right.$ $0.1, n=7$ ) and a Hill slope of $1.12 \pm 0.14$ (Fig. 3D and 3E). The ATP analogue Bz-ATP also evoked responses at $H d \mathrm{P} 2 \mathrm{X}$ with an $\mathrm{EC}_{50}$ of $12.2 \mu \mathrm{M}\left(\mathrm{pEC}_{50} 5.9 \pm 0.2, \mathrm{n}=5\right)$ and a Hill slope of $0.7 \pm 0.2$. The efficacy of Bz-ATP was lower $(\mathrm{p}<0.01)$ than ATP, with the maximum Bz-ATP response $64.6 \pm 5.7 \%$ that of the maximum response to ATP (Fig. 3D). Currents evoked by Bz-ATP had a slower rise time and rate of desensitization than equivalent ATP evoked currents ( $\mathrm{p}<0.01$ in both cases). With $100 \mu \mathrm{M}$ BzATP (maximal response) the time from 10\%-90\% peak current was $142.3 \pm 10.2 \mathrm{~ms}$ and the rate of current decay from peak to $50 \%$ was $446.4 \pm 38.9 \mathrm{~ms}(\mathrm{n}=7)$ (Fig. 3F). $\alpha \beta$-methylene ATP ( $\alpha \beta$ meATP) at $100 \mu \mathrm{M}$ evoked currents that were less than $50 \%$ of those evoked by $100 \mu \mathrm{M}$ ATP. $\mathrm{ADP}_{\text {hex }}$ (hexokinase treated ADP), adenosine, UDP and UTP at $100 \mu \mathrm{M}$ failed to elicit currents at $H d \mathrm{P} 2 \mathrm{X}$.

\section{Antagonists}

PPADS antagonised ATP evoked currents at $H d \mathrm{P} 2 \mathrm{X}$ with an $\mathrm{IC}_{50}$ of $15.0 \mu \mathrm{M}\left(\mathrm{pIC}_{50} 4.6 \pm 0.1, n=5\right)$ and a Hill slope of $-1.0 \pm 0.3$ for responses evoked by $100 \mu \mathrm{M}$ ATP (Fig. 4). Suramin also antagonised $H d \mathrm{P} 2 \mathrm{X}$ currents in a concentration dependent manner but not as strongly as PPADS. Suramin inhibited $100 \mu \mathrm{M}$ ATP responses with an $\mathrm{IC}_{50}$ of $22.6 \mu \mathrm{M}\left(\mathrm{pIC}_{50} 4.7 \pm 0.3, n=5-7\right)$ and a Hill slope of -0.8 \pm 0.3 . A component of the $H d \mathrm{P} 2 \mathrm{X}$ current was resistant to suramin and at the highest concentration tested (300 $\mu \mathrm{M}$ ), only 75\% of the $100 \mu \mathrm{M}$ ATP evoked response was inhibited (Fig. 4). 
A HaP2X
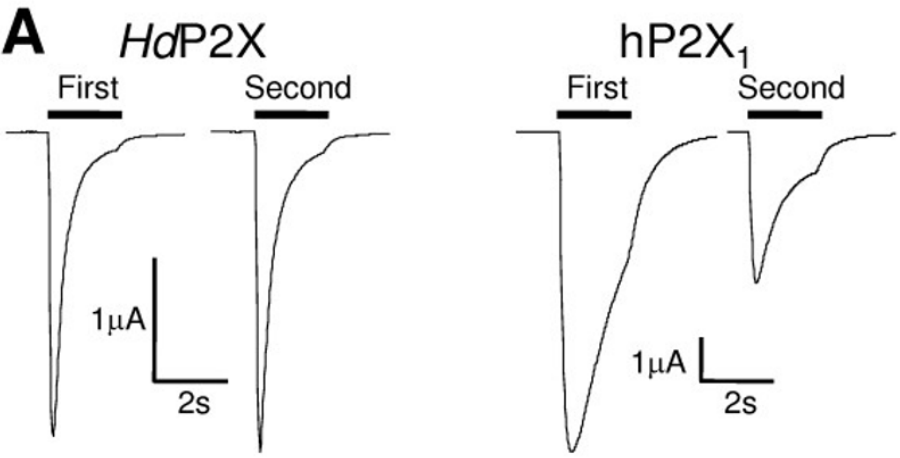

B
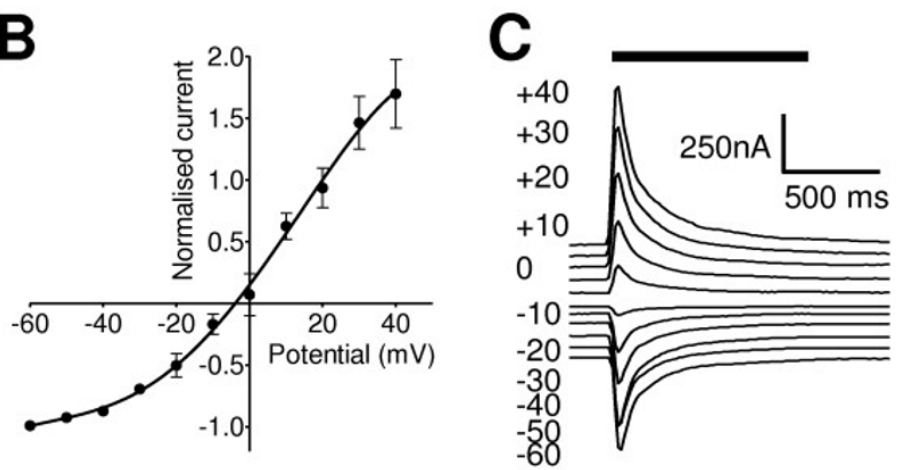

D
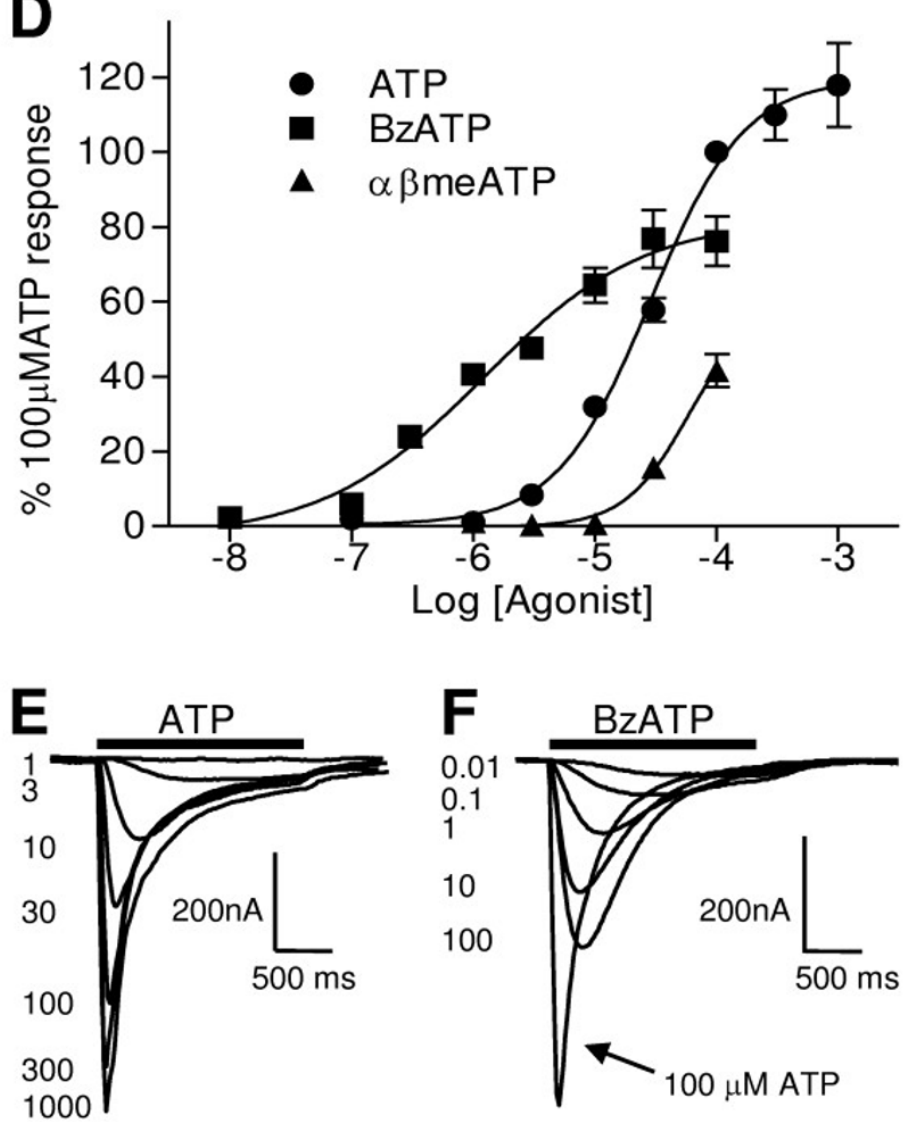

Figure 3 (see legend on next page) 
Figure 3 (see previous page)

Properties of ATP evoked currents. Two-electrode voltage clamp recordings at a holding membrane potential of $-60 \mathrm{mV}$ were made from oocytes expressing $H d P 2 X$. A. Comparison of $H d P 2 X$ and human $P 2 X$, receptors. Currents were recorded in response to $100 \mu \mathrm{M}$ ATP, indicated by bar. $\mathrm{HdP} 2 \mathrm{X}$ displays faster current rise and decay times than the human $\mathrm{P} 2 \mathrm{X}_{\mathrm{I}}$ and displays faster recovery from desensitisation between the first and second applications of agonist (applications 5 minutes apart). $B$. Current voltage relationship of $H d P 2 X$. The reversal potential of ATP mediated currents was determined by recording ATP ( $100 \mu \mathrm{M}$, indicated by bar) induced currents at holding potentials ranging from $-100 \mathrm{mV}$ to $+40 \mathrm{mV}$ with a 5 minute interval between applications. Currents obtained in different oocytes were normalised to the current obtained at $-60 \mathrm{mV}$ for each individual cell $(n=6)$. C. Example currents for the plot depicted in B. D. Concentration response curves for ATP, Bz-ATP and $\alpha \beta-$ me-ATP. Mean currents were normalised to the response given by $100 \mu M$ ATP $(n=5-7)$. E and F. Example currents recorded in response to ATP (E) and Bz-ATP (F) (concentrations in $\mu$ M, agonist application indicated by bar).

\section{HdP2X is inhibited by zinc and copper}

Vertebrate P2X receptors can be subject to allosteric modulation by both metal ions and $\mathrm{pH}$ [22]. Unlike some vertebrate P2X receptors [23], neither the ATP concentration response curve nor the amplitude of ATP evoked currents for $H d \mathrm{P} 2 \mathrm{X}$ were affected by acidic $\mathrm{pH}(\mathrm{pH} 6.5)(\mathrm{n}=5$, data not shown). The divalent cations zinc and copper however both caused concentration dependent inhibition of ATP-evoked currents (Fig. 5). Zinc inhibited $100 \mu \mathrm{M}$ ATP currents, with an $\mathrm{IC}_{50}$ of $62.8 \mu \mathrm{M}\left(\mathrm{pIC}_{50} 4.2 \pm 0.14, \mathrm{n}=5-\right.$ 6 ) and a Hill slope of $-0.7 \pm 0.1$. Copper also acted as an inhibitor of $100 \mu \mathrm{M}$ ATP currents with an $\mathrm{IC}_{50}$ of $19.9 \mu \mathrm{M}$ $\left(\mathrm{pIC}_{50} 4.7 \pm 0.06, \mathrm{n}=5-6\right)$ and a Hill slope of $-0.8 \pm 0.1$. (Fig. 5A). Histidine residues have previously been reported to be involved in zinc and copper inhibition of the $\mathrm{P} 2 \mathrm{X}_{7}$ receptor $[24,25]$ and also in the potentiation of $\mathrm{P}_{2} \mathrm{X}_{2}$ receptor currents by zinc [26]. Three histidine residues are present in the extracellular region of $H d \mathrm{P} 2 \mathrm{X}$ and we therefore mutated these residues to alanine both individually and in combination with each other in order to probe their potential involvement in metal ion binding. Using $100 \mu \mathrm{M}$ zinc as a test concentration, wild type currents evoked by $100 \mu \mathrm{M}$ ATP $\left(\sim \mathrm{EC}_{80}\right)$ were inhibited by $59.3 \pm 2.2 \%$. The inhibition observed for the single histidine mutants H232A, H252A and H306A and the double histidine mutants H232A/H252A, H252A/H306A and $\mathrm{H} 232 \mathrm{~A} / \mathrm{H} 306 \mathrm{~A}$ was not significantly different from wild type (Fig. 5B). The triple histidine mutant H232A/H252A/ H306A produced a non functional channel and therefore could not be studied. With copper $(100 \mu \mathrm{M})$ as the inhibitor, wild type currents were inhibited by $81.0 \pm 2.3 \%$. Similar to zinc, the inhibition observed in the single histidine and the H232A/H252A double mutant with copper did not significantly differ from wild type (Fig. 5B). The inhibition observed with the double mutants H232A/ H306A and H252A/H306A however was less than wild type ( $\mathrm{p}<0.05$ ) with $\mathrm{H} 232 \mathrm{~A} / \mathrm{H} 306 \mathrm{~A}$ currents inhibited by $60.0 \pm 3.9 \%$ and $\mathrm{H} 252 \mathrm{~A} / \mathrm{H} 306 \mathrm{~A}$ currents inhibited by $50.7 \pm 8.9 \%$. In order to assess whether mutation had resulted in a gross change in channel function, the potency of ATP for each histidine mutation was assessed (Fig. 5C) and none of the single or double mutations pro- duced a concentration response curve that differed significantly from wild type. Lysine, aspartic acid, and glutamic acid residues are also potential candidates for coordinating metal binding and a glutamic acid residue in rat $\mathrm{P} 2 \mathrm{X}_{7}$ has been shown to be involved in zinc and copper binding [25]. We therefore mutated lysine and negatively charged residues in $H d \mathrm{P} 2 \mathrm{X}$ that were specific between $H d \mathrm{P} 2 \mathrm{X}$ and $S$. mansoni $\mathrm{P} 2 \mathrm{X}$ since this channel is also sensitive to metal ions [27]. Five alanine substitution mutations were created (K297A, E249A, D183A, K130A and E110A) and tested for sensitivity to zinc and copper inhibition (Fig. 5B). No significant difference from the wild type inhibition for either zinc or copper was observed in any of these charged amino acid mutations.

\section{HdP2X currents are potentiated by Ivermectin}

Ivermectin, a broad spectrum anti-parasitic agent from the bacterium Streptomyces avermitilis is known to potentiate ATP-evoked currents at human and mouse P2X $\mathrm{X}_{4}[28,29]$ and the $S$. mansoni [12] P2X receptors. We therefore studied the effects of this allosteric modulator on the HdP2X receptor. Ivermectin alone was unable to activate the receptor (data not shown). However, $3 \mu \mathrm{M}$ ivermectin potentiated the response to a maximal concentration of ATP $(300 \mu \mathrm{M})$ by $223.8 \pm 14.1 \%$ of control responses, with no notable effect on the rates of current activation or decay (Fig. 6). Currents were significantly $(\mathrm{p}<0.01)$ potentiated in the presence of $3 \mu \mathrm{M}$ ivermectin at all concentrations of ATP investigated and the concentration response curve for ATP in the presence of $3 \mu \mathrm{M}$ ivermectin had an $\mathrm{EC}_{50}$ of $32.1 \mu \mathrm{M}\left(\mathrm{pEC}_{50} 4.5 \pm 0.1, n=5-10\right)$ and $\mathrm{a}$ Hill slope of $0.8 \pm 0.2$.

\section{Discussion}

Despite their absence in several key model organisms such as Saccharomyces cerevisiae, Drosophila melanogaster and Caenorhabditis elegans, functional $\mathrm{P} 2 \mathrm{X}$ receptors have now been described in a wide range of non-vertebrate metazoan phyla including platyhelminthes [12,27], and molluscs (41), and in representatives of other eukaryotic kingdoms such as dictyostelida [10], prasinophyceae [11] and choanoflagellates [11]. Additional partial and pre- 


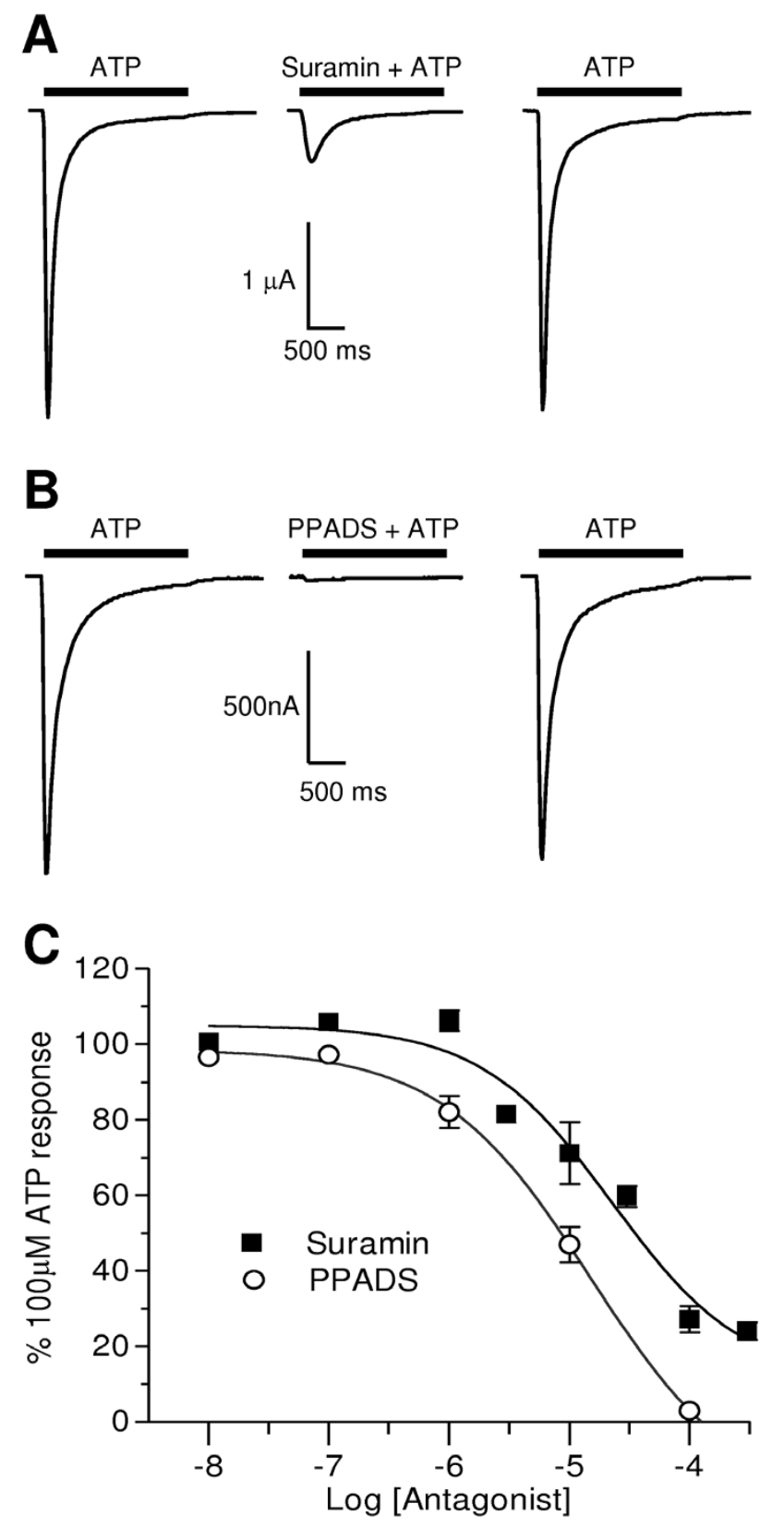

\section{Figure 4}

HdP2X is antagonised by suramin and PPADS. The effects of the P2 receptor antagonists suramin and PPADS were determined in Xenopus oocytes expressing HdP2X at a holding membrane potential of $-60 \mathrm{mV}$. A. Example currents in response to $100 \mu \mathrm{M}$ ATP in the presence and absence of $100 \mu \mathrm{M}$ suramin (five minutes between sequential applications). B. Example currents in response to $100 \mu \mathrm{M}$ ATP in the presence and absence of $100 \mu$ M PPADS (five minutes between sequential applications). C. Inhibition curves for mean responses to $100 \mu \mathrm{M}$ ATP in the presence of suramin (closed squares) $(n=5)$ and PPADS (open circles) $(n=5)$.
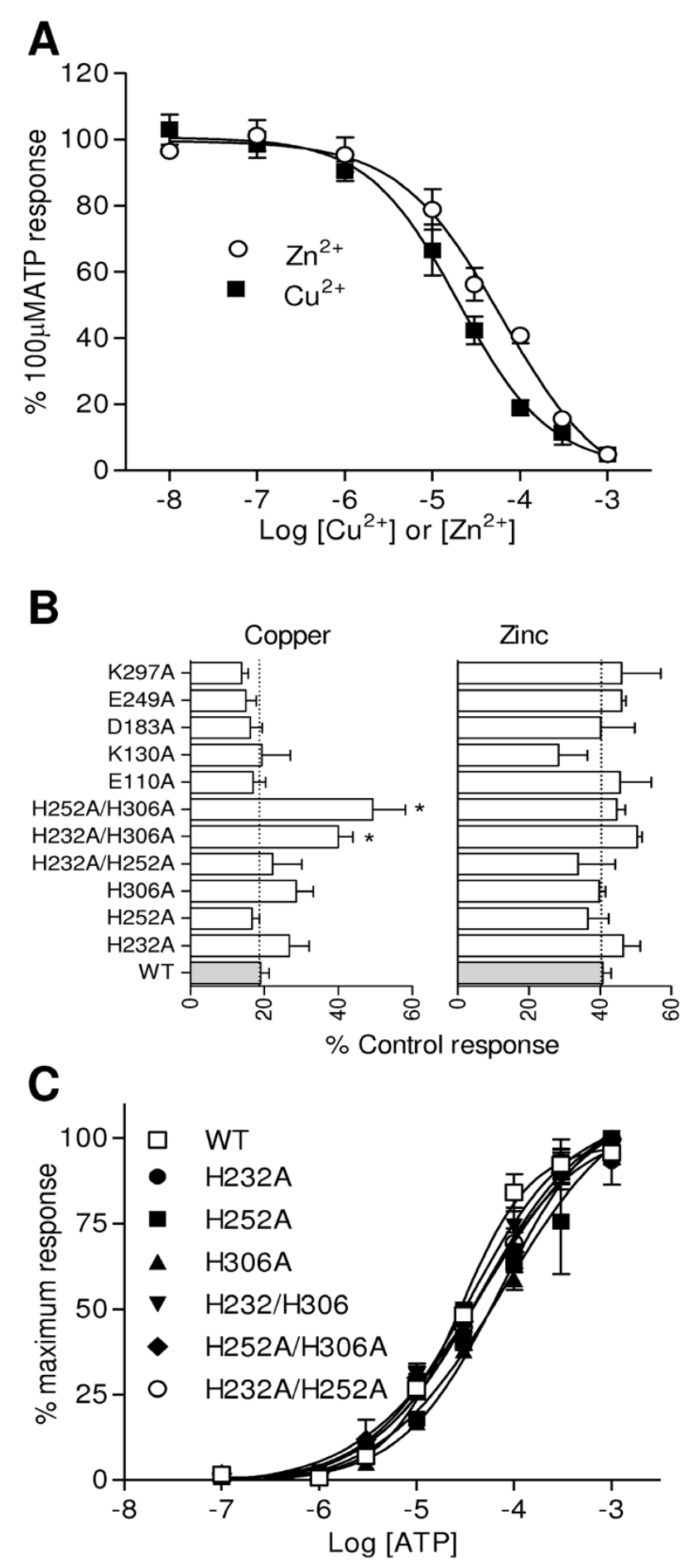

Figure 5 


\begin{abstract}
Figure 5
HdP2X receptor currents are inhibited by zinc and copper. Two-electrode voltage clamp recordings were made from Xenopus oocytes expressing $H d P 2 X$ at a holding potential of $-60 \mathrm{mV}$. A. Concentration response curves for $100 \mu \mathrm{M}$ ATP $\left(\sim \mathrm{EC}_{80}\right)$ in the presence of varying concentrations of zinc (open circles) $(n=6)$ and copper (closed squares) $(n=6)$. B. Effects of single and double point mutations on inhibition by $100 \mu \mathrm{M}$ zinc and copper. Mean currents are normalised to the $100 \mu \mathrm{M}$ ATP response in the absence of zinc or copper for wild type and mutant receptors $(n=7)$. C. ATP concentration response curves for histidine point mutations $(n=7)$. For each single and double histidine mutation no significant change in ATP sensitivity was observed suggesting that mutation had not resulted in gross changes in receptor conformation. The triple histidine mutation $\mathrm{H} 232 \mathrm{~A} / \mathrm{H} 252 \mathrm{~A} / \mathrm{H} 306 \mathrm{~A}$ produced a non functional channel and so could not be studied.
\end{abstract}

dicted P2X-like proteins can be identified in EST and partial genome data from other animals, including additional molluscs, echinoderms [30] and cnidaria. These data provide an emerging phylogenetic understanding of the evolution of ionotropic purinergic signalling. Alignment of $\mathrm{P} 2 \mathrm{X}$ proteins from a diverse range of taxa with the mammalian $\mathrm{P} 2 \mathrm{X}_{(1-7)}$ families (Fig. 2) clearly shows that the mammalian $\mathrm{P} 2 \mathrm{X}$ receptors are a lineagespecific gene expansion, with ortholog triplets evident in mouse, human and rat. A lineage-specific expansion is also evident in $D$. discoideum. In the other taxa, the single $\mathrm{P} 2 \mathrm{X}$ receptors identified appear to be orthologous to the entire vertebrate expansion. This strongly suggests that the emergence of a family of seven mammalian P2X receptors was a relatively recent evolutionary event that occurred subsequent to the split between vertebrates and invertebrates. The functional confirmation that $\mathrm{P} 2 \mathrm{X}$ receptors exist in the tardigrade $H$. dujardini strongly suggests that the loss of $\mathrm{P} 2 \mathrm{X}$ receptors in some nematode (represented by C. elegans) and arthropod (represented by the sequenced hexapod genomes) species occurred independently, as both traditional and molecular phylogenies place the divergence between Nematoda and Arthropoda before their divergence from Tardigrada. Pharmacological evidence for purinergic signalling in some nematode and arthropod species [6] suggests that P2X-like receptors may have been maintained in some members of these phyla. Indeed a partial transcript for a P2X gene from the nematode Xiphinema index [31] suggests that the loss of $\mathrm{P} 2 \mathrm{X}$ in C. elegans may have occurred relatively late in nematode evolution, and P2X-like ESTs from the chelicerate Boophilus microplus similarly suggest that the loss of P2X receptors in arthropods may be restricted to Hexapoda.

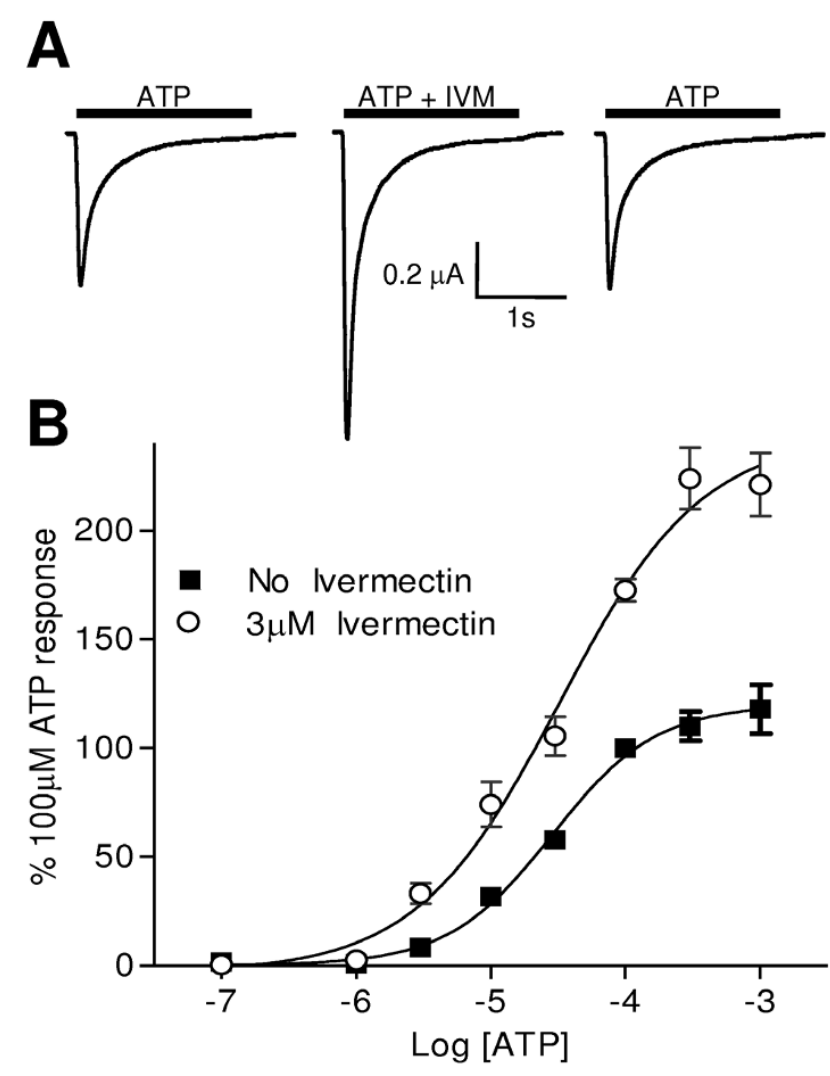

Figure 6

Ivermectin potentiates ATP evoked currents at HdP2X. Two-electrode voltage clamp recordings were made from Xenopus oocytes expressing HdP2X. A. Representative ATP $(100 \mu \mathrm{M})$ evoked currents recorded from the same cell in the presence and absence of $3 \mu \mathrm{M}$ ivermectin (ATP/ivermectin application indicated by bars). Five minutes recovery was allowed between applications and ivermectin was bath perfused at $3 \mu \mathrm{M}$ in the five minutes preceding the second recording as well as being present in the ATP application. B. Concentration response curves for ATP in the presence (open circles) and absence (closed squares) of $3 \mu \mathrm{M}$ ivermectin $(n=7)$. Mean currents were normalised to the response produced by $100 \mu \mathrm{M}$ ATP in the absence of ivermectin.

Based on their kinetic parameters and ligand sensitivity, mammalian P2X receptors can be divided into three groups [32]. Group 1 consists of $\mathrm{P} 2 \mathrm{X}_{1}$ and $\mathrm{P} 2 \mathrm{X}_{3}$ receptors that have high sensitivity for ATP $\left(\mathrm{EC}_{50} \sim 1-3 \mu \mathrm{M}\right)$ and show rapid channel activation and desensitisation during the continued presence of agonist. Group 2 includes $\mathrm{P} 2 \mathrm{X}_{2}$, $\mathrm{P} 2 \mathrm{X}_{4}, \mathrm{P} 2 \mathrm{X}_{5}$, and $\mathrm{P} 2 \mathrm{X}_{6}$ receptors with a lower sensitivity for ATP $\left(\mathrm{EC}_{50} \sim 10 \mu \mathrm{M}\right)$ and much slower desensitization whilst group 3 is represented by $\mathrm{P} 2 \mathrm{X}_{7}$ which has a very low sensitivity for ATP (EC ${ }_{50} \sim 300 \mu \mathrm{M}$ ) and shows little desensitization. HdP2X displays an unusual phenotype in 
that it has a relatively low sensitivity for ATP $\left(\mathrm{EC}_{50} \sim 44.5\right.$ $\mu \mathrm{M}$ ) but has very fast activation and desensitisation kinetics. This is interesting from a mechanistic point of view regarding the relationship between channel gating and agonist binding since it demonstrates that that fast channel kinetics do not necessarily have to be associated with a high agonist sensitivity. Similar to $\mathrm{HdP} 2 \mathrm{X}$, a $\mathrm{P} 2 \mathrm{X}_{3}$-like receptor from Zebrafish has also been shown to combine fast current kinetics with low sensitivity to ATP [33]. However, unlike $H d \mathrm{P} 2 \mathrm{X}$ (Fig. 3A) current amplitudes at the Zebrafish channel never fully recover from the first stimulation. Other lower organism P2X receptors that have been characterised to date have all displayed slow rates of desensitisation making $H d \mathrm{P} 2 \mathrm{X}$ the first example of a non vertebrate P2X channel with fast kinetics. Given that it is likely that a fast phenotype evolved independently in $\mathrm{P} 2 \mathrm{X}_{1,3}$ and $H d \mathrm{P} 2 \mathrm{X}$ channels, it will be interesting to determine whether the same factors determine the rates of current activation and desensitisation in these evolutionary remote channels.

HdP2X contains several amino acid residues that are highly conserved throughout the vertebrate P2X receptor family. The ten conserved cysteine residues present in the extracellular loop of all vertebrate $\mathrm{P} 2 \mathrm{X}$ receptors are thought to form five disulphide bonds [2] and these residues are also present in $H d \mathrm{P} 2 \mathrm{X}$ suggesting conservation of gross extracellular structure constrained by disulphide bond location. It is interesting to note that the P2X receptors from $O$. tauri and $M$. brevicollis [11] possess only eight of these ten conserved cysteine residues in their putative extracellular regions and that in each case the two absent cysteines correspond to a proposed disulphide bond pairing in the human $\mathrm{P} 2 \mathrm{X}_{1}$ receptor [2] (the equivalents of $\mathrm{hP} 2 \mathrm{X}_{1} \mathrm{C} 217$ and C227 are absent in O. tauri and C117 and $\mathrm{C} 165$ are absent in M. brevicollis). The agonist binding site of P2X receptors is distinct from other ATP-binding proteins and is thought to be formed from the interaction between adjacent subunits [34]. Based on site directed mutagenesis combined with methanethiosulfonate reactivity a core common mode of action of ATP binding at $\mathrm{P} 2 \mathrm{X}$ receptors has been proposed consisting of lysine residues adjacent to the transmembrane domains coordinating phosphate binding, an NFR motif binding the adenine/ribose moiety and an FT motif also involved in agonist action [21]. The lysine residues, NFR and FT motifs are also present in $H d \mathrm{P} 2 \mathrm{X}$ (Fig. 1) suggesting that this mechanism of ATP binding arose relatively early in evolution and is not restricted to mammalian receptors. However, the NFR motif and the equivalent of hP2X $\mathrm{X}_{1} \mathrm{~K} 68$ are absent in the D. discoideum P2XA receptor [10], the FT motif is YT in S. mansoni P2X [12] and the NFR motif is NIR in the $O$. tauri [11] receptor suggesting that conservation of the residues involved in ATP binding is not universal to all P2X receptors. Residues at positions D280 and
$\mathrm{R} 278$ in the rat $\mathrm{P} 2 \mathrm{X}_{4}$ receptor have also been shown to play an important role in the action of ATP [35]. These residues are also conserved in $H d \mathrm{P} 2 \mathrm{X}, S$. mansoni $\mathrm{P} 2 \mathrm{X}$ and $\mathrm{M}$. brevicollis $\mathrm{P} 2 \mathrm{X}$ suggesting that, despite their incomplete conservation amongst the seven mammalian P2X subtypes, these two residues may also play an important role in the formation of the ATP binding site in some P2X receptor subtypes. Interestingly, the only feature with complete conservation across all vertebrate and lower organism P2X receptors characterised to date is a consensus protein kinase $\mathrm{C}$ phosphorylation site in the N-terminal tail of the receptor (Fig. 1). This putative phosphorylation site has been shown to regulate desensitisation in both $\mathrm{P} 2 \mathrm{X}_{1}[36]$ and $\mathrm{P} 2 \mathrm{X}_{2}[20]$ receptors however, surprisingly direct phosphorylation of this site has been shown not to occur $[37,38]$.

Unlike the D. discoideum [10] and O. tauri [11] P2X receptors, the general $\mathrm{P} 2$ receptor antagonists suramin and PPADS both inhibited HdP2X receptor currents in a concentration dependent manner. PPADS at $100 \mu \mathrm{M}$ effectively blocked ATP evoked currents. Suramin however was less potent and a component of the current was resistant to antagonism by suramin even at high concentrations. At the highest concentration tested $(300 \mu \mathrm{M})$ only $~ 75 \%$ of the $100 \mu \mathrm{M}$ ATP-evoked current was blocked. These properties are opposite to those of the S. mansoni P2X, which was more potently inhibited by suramin and incompletely blocked by PPADS [12]. The presence of a lysine residue at position 246 in rat $\mathrm{P} 2 \mathrm{X}_{2}$ and at equivalent positions in other mammalian subunits has been proposed to be involved in the inhibition of P2X receptors by PPADS, possibly forming a Schiff base with the aldehyde group of PPADS [39]. Similarly a lysine residue at position 138 in human $\mathrm{P}_{2} \mathrm{X}_{1}$ has recently been shown to play a key role in the binding of suramin [40]. Neither of these lysine residues shown to be involved in PPADS and suramin action at mammalian receptors are conserved in either $H d \mathrm{P} 2 \mathrm{X}$ or S. mansoni $\mathrm{P} 2 \mathrm{X}$ suggesting that additional residues in the ectodomain also play key roles in the mechanism of antagonist binding.

$H d \mathrm{P} 2 \mathrm{X}$ is inhibited by both copper and zinc in a concentration dependent manner (Fig. 5). The effects of these metal ions on vertebrate $\mathrm{P} 2 \mathrm{X}$ receptors differ markedly with $\mathrm{P} 2 \mathrm{X}_{1}$ being inhibited by zinc, $\mathrm{P} 2 \mathrm{X}_{7}$ inhibited by both zinc and copper, $\mathrm{P} 2 \mathrm{X}_{2}$ potentiated by both zinc and copper and $\mathrm{P} 2 \mathrm{X}_{4}$ potentiated by zinc but inhibited by copper (reviewed by [41]). The action of these metal ions at P2X receptors has physiological significance since both zinc and copper are stored in presynaptic terminals and released after nerve stimulation $[41,42]$. In addition to $H d \mathrm{P} 2 \mathrm{X}$, the modulation of $\mathrm{P} 2 \mathrm{X}$ receptors by metal ions is also present in other lower organisms with Dictyostelium P2X inhibited by copper [10] and S. mansoni P2X inhib- 
ited by zinc [27]. Several mutagenic studies have identified amino acid residues involved in metal binding in P2 $\mathrm{X}_{2,4 \text { and } 7}$ receptors (reviewed by [41]) however, no consensus binding site has emerged showing independent evolution of metal binding sites among the different vertebrate $\mathrm{P} 2 \mathrm{X}$ receptor subtypes. Histidine residues appear to be a common feature in metal binding sites in $\mathrm{P} 2 \mathrm{X}_{2,4}$ and 7 receptors (reviewed by[41]) and in rat $\mathrm{P}_{2} \mathrm{X}_{2}, \mathrm{H} 120$ and $\mathrm{H} 213$ have been shown to form an intersubunit zinc binding site [26]. There are three extracellular histidine residues present in $H d \mathrm{P} 2 \mathrm{X}$ and we mutated each of these residues, both individually and in combination with each other, to alanine in order to assess their involvement in metal binding. Surprisingly, none of the extracellular HdP2X histidine residues are essential for inhibition by zinc or copper (Fig. 5B). This demonstrates that the mechanisms by which metal ions can influence the properties of P2X receptor function are not restricted to interactions with histidine residues. However, mutation of H306 in combination with either $\mathrm{H} 252$ or $\mathrm{H} 232$ did produce a significant reduction in copper but not zinc inhibition. This suggests that $\mathrm{H} 306$ plays a minor but non critical role in the formation of the copper binding site and that the copper and zinc binding sites in $H d \mathrm{P} 2 \mathrm{X}$ are distinct from one another. Distinct zinc and copper binding sites are also likely for $\mathrm{P}_{2} \mathrm{X}_{4}$ which is potentiated by zinc but inhibited by copper [43].

Of the currently identified vertebrate and lower organism $\mathrm{P} 2 \mathrm{X}$ receptors only human and rat $\mathrm{P}_{2} \mathrm{X}_{4}[29]$ and S. mansoni $\mathrm{P} 2 \mathrm{X}[12$ ] are known to be potentiated by the semi synthetic macrocyclic lactone ivermectin. Both $\mathrm{P}_{2} \mathrm{X}_{4}$ and $S$. mansoni $\mathrm{P} 2 \mathrm{X}$ have a slow current phenotype and it is therefore interesting with respect to the mechanism of ivermectin action that $H d \mathrm{P} 2 \mathrm{X}$ which has very fast current activation and desensitisation kinetics is also potentiated (Fig. 6). Ivermectin does not affect the kinetics of desensitization of $H d \mathrm{P} 2 \mathrm{X}$ currents, a feature also observed in $S$. mansoni P2X. However, in human $\mathrm{P}_{2} \mathrm{X}_{4}$, ivermectin confers a slower rate of desensitization [29]. Ivermectin is thought to have an allosteric mode of action by increasing maximum current when binding to a high affinity site on the receptor to stabilise the open state, whereas binding to a low affinity site is proposed to slow the rate of deactivation [44]. More recently it was proposed that during gating TM1 rotates relative to TM2, and ivermectin is able to access the lipid environment and optimally bind to a hydrophobic crevice created by TM1 and TM2 at the protein-lipid interface [45]. Interestingly several hydrophobic-nonpolar residues in both TM1 and TM2 that have been shown to be involved in the action of ivermectin at $\mathrm{P} 2 \mathrm{X}_{4}$ are conserved in S. mansoni P2X [28] and these hydrophobic-nonpolar residues are mostly also present $\mathrm{HdP} 2 \mathrm{X}$. Future investigations comparing the mode of ivermectin action in both naturally fast and slow desensitising
P2X channels may enhance our understanding of the process of gating and motions of the channel pore.

\section{Conclusion}

The identification and pharmacological characterisation of a P2X receptor from $H$. dujardini provides further evidence that $\mathrm{P} 2 \mathrm{X}$ receptors for ATP emerged early in eukaryotic evolution. Several unusual characteristics of $H d \mathrm{P} 2 \mathrm{X}$ including fast current kinetics with low ATP sensitivity, ivermectin potentiation in a channel with fast kinetics and the likelihood of distinct copper and zinc metal binding sites make this channel a useful model for comparative structure-function studies allowing a better understanding of P2X receptors in higher organisms.

\section{Methods \\ Identification of the Hypsibius dujardini $\mathrm{P} 2 \mathrm{X}$ receptor}

BLAST searches of the GenBank EST database identified a partial Hypsibius dujardini EST sequence [GenBank:CO741227] encoding a peptide with significant sequence similarity to the amino terminus of vertebrate $\mathrm{P} 2 \mathrm{X}$ receptors. The insert of the corresponding clone for this EST sequence (Hd_mx23_13F10) was fully sequenced on both strands (Automated ABI sequencing service, Leicester University, U.K.) using vector (pSPORT1) and insert specific primers and was shown to contain a full length coding sequence which was named $\mathrm{HdP} 2 \mathrm{X}$

\section{Phylogenetic analysis}

P2X protein sequences were obtained from SwissProt/ UniProt and aligned with ClustalW. The alignment was adjusted by eye to minimise unique indels and subjected to phylogenetic analysis in PAUP* version $4.10 \mathrm{~b}$ using Neighbour Joining (BioNJ) and maximum parsimony methods. The alignment was 696 characters long, and had 147 invariant and 433 parsimony-informative characters. As the N-terminal and C-terminal portions of the proteins were poorly aligned, the analysis considered only the central 445 characters (of which 342 were parsimony informative, and 208 included gaps). The alignment is available from the authors (MLB). Support for the derived phylogenies was assessed by 1000 bootstrap iterations.

\section{Site directed mutagenesis}

Point mutations in the $\mathrm{Hd} \mathrm{P} 2 \mathrm{X}$ plasmid construct were introduced using the QuikChange $\mathrm{T}^{\mathrm{TM}}$ Mutagenesis Kit (Stratagene, U.S.A.) according to the manufacturer's instructions. Histidines at positions 232, 252 and 306, glutamic acid residues at positions 110 and 249, an aspartic acid residue at position 183 and lysine residues at positions 130 and 297 were mutated to alanine. Double mutations where two of the three histidines were both mutated to alanine were created by conducting serial rounds of site directed mutagenesis as follows: H252A/ 
H232A, H252A/H306A, H232A/H306A. A triple mutant where all three histidines were mutated to alanine was constructed by introducing the H306A mutation into the H252A/H232A double mutant. In all mutants, introduction of the correct mutation(s) and the absence of spontaneous mutations were confirmed by DNA sequencing (Automated ABI sequencing service, Leicester University).

\section{Oocyte preparation}

Mutant and wild type plasmids were digested with NotI to linearise and sense strand cRNA was generated using the T7 mMessage mMachine ${ }^{\mathrm{TM}}$ kit (Ambion, U.S.A.) according to the manufacturer's instructions. Manually defolliculated stage V-VI Xenopus oocytes were injected with $5 \mathrm{ng}$ of cRNA (50 nl at a concentration of $0.1 \mu \mathrm{g} / \mu \mathrm{l}$ ) using an Inject +Matic micro injector (J. Alejandro Gaby, Genève) and were stored at $18^{\circ} \mathrm{C}$ in ND96 buffer $(96 \mathrm{mM} \mathrm{NaCl}, 2$ $\mathrm{mM} \mathrm{KCl}, 1.8 \mathrm{mM} \mathrm{CaCl}_{2}, 1 \mathrm{mM} \mathrm{MgCl}_{2}, 5 \mathrm{mM}$ sodium pyruvate, and $5 \mathrm{mM}$ HEPES, pH 7.5) before electrophysiological recordings were carried out 3-6 days later.

\section{Two-electrode voltage clamp}

Two-electrode voltage clamp recordings were made from oocytes using a Turbo TEC 10C amplifier (NPI Electronic Instruments, Germany) with a Digidata 1200 analogue to digital converter (Axon Instruments U.S.A.) and WinWCP acquisition software (Dr J. Dempster University of Strathclyde, Scotland). Microelectrodes were filled with $3 \mathrm{M}$ $\mathrm{KCl}$, and the external solution consisted of ND96 buffer with $1.8 \mathrm{mM} \mathrm{CaCl}_{2}$ replaced with $1.8 \mathrm{mM} \mathrm{BaCl}^{2}$ to prevent the activation of endogenous calcium-activated chloride channels. Membrane currents were recorded at a holding potential of $-60 \mathrm{mV}$. Agonists, ATP $\left(\mathrm{Mg}^{2+}\right.$ salt $)$, 2',3'-O-4-Benzoylbenzoyl ATP (Bz-ATP) and $\alpha, \beta$-methylene-adenosine 5'-triphosphate ( $\alpha \beta$ meATP) (Sigma, Poole, U.K.) were applied from a U-tube perfusion system, whereas ivermectin, pyridoxal-phosphate-6-azophenyl-2',4'-disulfonic acid (PPADS), suramin, zinc, copper and altered $\mathrm{pH}$ solutions were bath-perfused as well as being present at the same concentration in the U-tube solution together with the agonist. Concentrationresponse curves were constructed by having a 5-minute recovery period between applications and by normalizing data points to two applications (one preceding and one following the test agonist/antagonist concentration). 100 $\mu \mathrm{M}$ ATP was used for normalisation as this concentration produced reproducible responses with a 5 minute recovery interval.

\section{Data analysis}

Data are presented as means \pm S.E. Differences between means were assessed by either the Student's t-test for simple comparison between two data sets or by ANOVA followed by Dunnett's post test when multiple data sets were compared (GraphPad Prism software (La Jolla, USA)).
Concentration-response data were fitted with the equation $Y=\left((X)^{H} \cdot M\right) /\left((X)^{H}+\left(E_{50}\right)^{H}\right)$, where $Y$ is response, $X$ is agonist concentration, $H$ is the Hill coefficient, $M$ is maximum response, and $\mathrm{EC}_{50}$ is the concentration of agonist evoking $50 \%$ of the maximum response. $\mathrm{pEC}_{50}$ is the $-\log _{10}$ of the $\mathrm{EC}_{50}$ value. All concentration-response curves, $\mathrm{EC}_{50}$ values and Hill coefficients were obtained using GraphPad Prism software.

\section{Abbreviations}

PPADS: Pyridoxal-phosphate-6-azophenyl-2',4' disulfonic acid; $\alpha \beta$ meATP: $\alpha, \beta$-methylene-adenosine 5 '-triphosphate; $\mathrm{ADP}_{\text {hex }}$ : Hexokinase treated ADP.

\section{Authors' contributions}

SB carried out electrophysiological recordings, wrote the first draft of the manuscript and analysed the data. VAS participated in the design of the study and helped draft the manuscript. MLB conducted the phylogenetic analysis, helped draft the manuscript and generated the HdP2X EST clone. SJE conceived and designed the study, performed the molecular biological aspects of the study and wrote the manuscript. All authors read and approved the final manuscript.

\section{Acknowledgements}

SB was funded by a studentship from the Biotechnology and Biological Sciences Research Council. MLB and VS were funded by the Biotechnology and Biological Sciences Research Council and SJE was funded by project grant WT08I60IMA from the Wellcome Trust.

\section{References}

I. Khakh BS, North RA: P2X receptors as cell-surface ATP sensors in health and disease. Nature 2006, 442(7/ 02):527-532.

2. Ennion SJ, Evans RJ: Conserved cysteine residues in the extracellular loop of the human $\mathrm{P} 2 \mathrm{X}$ (I) receptor form disulfide bonds and are involved in receptor trafficking to the cell surface. Mol Pharmacol 2002, 6 I (2):303-3II.

3. Ennion S, Hagan S, Evans RJ: The role of positively charged amino acids in ATP recognition by human $P 2 X I$ receptors. J Biol Chem 2000, 275(45):35656.

4. Roberts JA, Vial C, Digby HR, Agboh KC, Wen H, Atterbury-Thomas A, Evans RJ: Molecular properties of $\mathbf{P} 2 \mathbf{X}$ receptors. Pflugers Arch 2006, 452(5):486-500.

5. North RA: Molecular physiology of P2X receptors. Physiol Rev 2002, 82(4): 1013-1067.

6. Burnstock G: Purinoceptors: ontogeny and phylogeny. Drug Dev Res 1996, 39:204-242.

7. Kim SY, Sivaguru M, Stacey G: Extracellular ATP in plants. Visualization, localization, and analysis of physiological significance in growth and signaling. Plant Physiol 2006, I 42(3):984-992.

8. Roux SJ, Steinebrunner I: Extracellular ATP: an unexpected role as a signaler in plants. Trends Plant Sci 2007, I 2(I I):522-527.

9. Burnstock G: Cotransmission. Curr Opin Pharmacol 2004, 4(I):47-52.

10. Fountain S], Parkinson K, Young MT, Cao L, Thompson CR, North $\mathrm{RA}$ : An intracellular $\mathbf{P} \mathbf{2 X}$ receptor required for osmoregulation in Dictyostelium discoideum. Nature 2007, 448(7I 50):200-203.

II. Fountain SJ, Cao L, Young MT, North RA: Permeation properties of a $\mathbf{P} 2 \mathrm{X}$ receptor in the green algae Ostreococcus tauri. J Biol Chem 2008, 283(22): $15122-15126$. 
12. Agboh KC, Webb TE, Evans RJ, Ennion SJ: Functional characterization of a P2X receptor from Schistosoma mansoni. J Biol Chem 2004, 279(40):41650-4I657.

13. Bavan S, Straub V, Ennion S: Pharmacological characterisation of a $\mathrm{P2X}$ receptor cloned from the central nervous system of Lymnaea stagnalis. Purinergic Signalling 2008, 4(Supplement 5):SI.

14. Nelson DR, Higgins RP: Tardigrada. In Soil Biology Guide Edited by: DL D. New York: John Wiley \& Sons; 1990:393-419.

15. Gabriel WN, McNuff R, Patel SK, Gregory TR, Jeck WR, Jones CD, Goldstein B: The tardigrade Hypsibius dujardini, a new model for studying the evolution of development. Dev Biol 2007 3 I 2(2):545-559.

16. Kinchin IM: The Biology of Tardigrades. London: Portland Press; 1994.

17. Aguinaldo AM, Turbeville JM, Linford LS, Rivera MC, Garey JR, Raff RA, Lake JA: Evidence for a clade of nematodes, arthropods and other moulting animals. Nature 1997, 387(6632):489-493.

18. Dopazo H, Dopazo J: Genome-scale evidence of the nematodearthropod clade. Genome Biol 2005, 6(5):R4I.

19. Claros MG, von Heijne G: TopPred II: an improved software for membrane protein structure predictions. Comput Appl Biosci 1994, 10(6):685-686.

20. Boue-Grabot E, Archambault V, Seguela P. A protein kinase $C$ site highly conserved in P2X subunits controls the desensitization kinetics of P2X(2) ATP-gated channels. J Biol Chem 2000 , 275(14): $10190-10195$.

21. Roberts JA, Digby HR, Kara M, Ajouz SE, Sutcliffe MJ, Evans RJ: Cysteine Substitution Mutagenesis and the Effects of Methanethiosulfonate Reagents at P2X2 and P2X4 Receptors Support a Core Common Mode of ATP Action at P2X Receptors. J Biol Chem 2008, 283(29):20|26-20I36.

22. Evans RJ: Orthosteric and allosteric binding sites of P2X receptors. Eur Biophys J 2008.

23. Gerevich Z, Zadori ZS, Koles L, Kopp L, Milius D, Wirkner K, Gyires $K$, llles P: Dual effect of acid $\mathbf{p H}$ on purinergic $\mathbf{P} 2 X 3$ receptors depends on the histidine 206 residue. J Biol Chem 2007 282(47):33949-33957.

24. Acuna-Castillo C, Coddou C, Bull P, Brito J, Huidobro-Toro JP: Differential role of extracellular histidines in copper, zinc, magnesium and proton modulation of the $\mathrm{P} 2 \times 7$ purinergic receptor. J Neurochem 2007, I0I(I): 17-26.

25. Liu X, Surprenant A, Mao HJ, Roger S, Xia R, Bradley H, jiang LH: Identification of key residues coordinating functional inhibition of P2X7 receptors by zinc and copper. Mol Pharmacol 2008, 73(I):252-259.

26. Nagaya N, Tittle RK, Saar N, Dellal SS, Hume RI: An intersubunit zinc binding site in rat $\mathbf{P 2 X 2}$ receptors. J Biol Chem 2005, 280(28):25982-25993.

27. Raouf R, Blais $D$, Seguela $P$ : High zinc sensitivity and pore formation in an invertebrate $\mathbf{P} \mathbf{2 X}$ receptor. Biochim Biophys Acta 2005 , |669(2): $|35-| 4 \mid$

28. Jelinkova I, Vavra V, Jindrichova M, Obsil T, Zemkova HW, Zemkova $\mathrm{H}$, Stojilkovic SS: Identification of P2X(4) receptor transmembrane residues contributing to channel gating and interaction with ivermectin. Pflugers Arch 2008, 456(5):939-950.

29. Khakh BS, Proctor WR, Dunwiddie TV, Labarca C, Lester HA: Allosteric control of gating and kinetics at $P 2 X(4)$ receptor channels. J Neurosci 1999, I 9( I 7):7289-7299.

30. Fountain S], Burnstock G: An evolutionary history of $\mathbf{P} 2 \mathbf{X}$ receptors. Purinergic Signal 2008.

31. Wasmuth J, Schmid R, Hedley A, Blaxter M: On the extent and origins of genic novelty in the phylum nematoda. PLoS Negl Trop Dis 2008, 2(7):e258.

32. Burnstock G, Williams M: $\mathbf{P 2}$ purinergic receptors: modulation of cell function and therapeutic potential. J Pharmacol Exp Ther 2000, 295(3):862-869.

33. Boue-Grabot E, Akimenko MA, Seguela P: Unique functional properties of a sensory neuronal P2X ATP-gated channel from zebrafish. J Neurochem 2000, 75(4):1600-1607.

34. Marquez-Klaka B, Rettinger J, Bhargava Y, Eisele T, Nicke A: Identification of an intersubunit cross-link between substituted cysteine residues located in the putative ATP binding site of the P2XI receptor. J Neurosci 2007, 27(6): | 456-| 466.

35. Zemkova H, Yan Z, Liang Z, Jelinkova I, Tomic M, Stojilkovic SS: Role of aromatic and charged ectodomain residues in the $\mathbf{P} 2 \mathbf{X}(4)$ receptor functions. J Neurochem 2007, I 02(4): I I39-II50.
36. Ennion SJ, Evans RJ: $\mathbf{P} 2 \mathbf{X}(\mathrm{I})$ receptor subunit contribution to gating revealed by a dominant negative PKC mutant. Biochem Biophys Res Commun 2002, 29 I (3):6I I-6I6.

37. Vial C, Tobin AB, Evans RJ: G-protein-coupled receptor regulation of P2XI receptors does not involve direct channel phosphorylation. Biochem J 2004, 382(Pt I): I0 I- I I0.

38. Franklin C, Braam U, Eisele T, Schmalzing G, Hausmann R: Lack of evidence for direct phosphorylation of recombinantly expressed $\mathbf{P} 2 X(2)$ and $\mathbf{P} 2 X$ (3) receptors by protein kinase C. Purinergic Signal 2007, 3(4):377-388.

39. Buell G, Lewis C, Collo G, North RA, Surprenant A: An antagonistinsensitive P2X receptor expressed in epithelia and brain. Embo J 1996, I 5(I):55-62.

40. Sim JA, Broomhead HE, North RA: Ectodomain lysines and suramin block of $\mathbf{P 2 X}$ I receptors. J Biol Chem 2008.

4l. Huidobro-Toro JP, Lorca RA, Coddou C: Trace metals in the brain: allosteric modulators of ligand-gated receptor channels, the case of ATP-gated P2X receptors. Eur Biophys J 2008, 37(3):30I-314

42. Li C, Peoples RW, Weight FF: Cu2+ potently enhances ATPactivated current in rat nodose ganglion neurons. Neurosci Lett 1996, 219(1):45-48.

43. Xiong K, Peoples RW, Montgomery JP, Chiang Y, Stewart RR, Weight FF, Li C: Differential modulation by copper and zinc of P2X2 and P2X4 receptor function. IJ Neurophysiol 1999, 8 I (5):2088-2094.

44. Priel A, Silberberg SD: Mechanism of ivermectin facilitation of human P2X4 receptor channels. J Gen Physiol 2004, I 23(3):28I-293.

45. Silberberg SD, Li M, Swartz KJ: Ivermectin Interaction with transmembrane helices reveals widespread rearrangements during opening of P2X receptor channels. Neuron 2007, 54(2):263-274.

Publish with BioMed Central and every scientist can read your work free of charge

"BioMed Central will be the most significant development for disseminating the results of biomedical research in our lifetime. "

Sir Paul Nurse, Cancer Research UK

Your research papers will be:

- available free of charge to the entire biomedical community

- peer reviewed and published immediately upon acceptance

- cited in PubMed and archived on PubMed Central

- yours - you keep the copyright
BioMedcentral 